\title{
Factors Influencing Cloud Computing Adoption by Small and Medium-Sized Enterprises (SMEs) In India
}

\author{
Devesh Kumar \\ LM Thapar School of Management \\ Thapar University, Patiala, Punjab, India \\ devesh.shrma@gmail.com \\ Harsh Vardhan Samalia \\ Rajiv Gandhi Indian Institute of Management \\ Shillong, India \\ hvs@iimshillong.ac.in \\ Piyush Verma \\ LM Thapar School of Management \\ Thapar University, Patiala, Punjab, India \\ pverma@thapar.edu
}

\begin{abstract}
The purpose of this paper is to examine and assess the determinants of cloud computing adoption by small and medium-sized enterprises (SMEs) in an Indian context through an integrated research framework. A questionnaire based survey method was used to collect data from 271 SMEs from the northern region of India. An integrated model founded on Technology Acceptance Model (TAM), Diffusion of Innovation (DOI) and Technology-OrganizationEnvironment (TOE) was proposed to test ten hypotheses through a confirmatory factor analysis and structural equation modelling. The analysis reveals that relative advantage, security concerns, top management support, external pressure and service providers' support are the significant factors which influence intention to adopt cloud computing by SMEs in India. The integrated research framework used and validated in this study is intended to enhance the predictive power of the ensuing model. The empirically validated research model and the instrument used for data collection can be adopted in other similar studies. The findings of this study can be useful for consumers, practitioners, and policy makers who are involved in utilizing, spreading and promoting the adoption of cloud computing among organizations, especially the SMEs.
\end{abstract}

Keywords: Cloud computing, adoption, India, SMEs, ICT, TOE

Citation: Kumar, D., Samalia, H. V. and Verma, P. (2017). "Factors Influencing Cloud Computing Adoption by Small and Medium-Sized Enterprises (SMEs) In India," Pacific Asia Journal of the Association for Information Systems, 9(3), pp. 25-48. 


\section{Introduction}

Cloud computing is an innovative method of providing relevant information and communication technologies (ICTs) to customers on-demand and on a pay-perusage basis through the internet. The adoption of appropriate ICTs help organizations in streamlining their processes, improving quality and increasing their market reach. Cloud computing has the potential to make available the necessary ICT infrastructure to enterprises at minimum cost and efforts. In addition to cost and effort benefits, cloud computing also provides improved back-up and business continuity services, automatic provisioning of resources and hassle-free implementation and maintenance (Armbrust et al., 2010). All these benefits and features make cloud computing an attractive option for all types of organizations.

Cloud computing has exceptional significance for small and medium-sized enterprises (SMEs). In developing nations, SMEs are considered as the growth engine of the economy. However, at the same time, SME sector faces many challenges in the form of limited capital, lack of skilled manpower and low level of ICT penetration (Shiralashetti, 2012). These challenges deprive SMEs of many benefits of using ICT, which are hard to ignore in the current competitive and volatile business environment. Very high cost and expertise required to use and maintain a modern ICT infrastructure hinders SMEs from adopting ICTs (Tan et al., 2009). However, with cloud computing, the situation is expected to change phenomenally. Cloud computing has potential to make available modern and most appropriate ICTs to SMEs without making heavy investments and efforts. The benefits derived from ICT adoption through cloud computing enable SMEs to become more competitive and agile to rapidly changing market conditions.

Despite the hyped benefits of cloud computing, the literature suggests that a very few SMEs have adopted cloud computing in developing economies like India (Malviya and Chakraborty, 2013; Bhat, 2013). Limited number of studies exist on adoption of cloud computing by SMEs, especially in a developing economy context like India. Various theoretical models, constructs, and methodologies are used by researchers to assess important factors influencing adoption of cloud computing by SMEs (Al-Isma'ili et al., 2016; Prasad and Green, 2015; Khan and Al-Yasiri, 2016; Abdullah and Hassan, 2015; Alshamaila et al., 2013). A common limitation reported in these studies is the use of a limited set of variables relevant to the subject and context. Therefore, a more comprehensive model founded on prominent and relevant technology adoption theories covering all the essential factors is required. The factors selected should be relevant to the technology i.e. cloud computing and its adoption among SMEs. Owing to these observations, the present study attempts to assess crucial factors influencing adoption of cloud computing among Indian SMEs. The study employs and integrates three renowned theoretical models for this purpose. The findings are intended to help SMEs in understanding important factors to consider for, while planning to adopt cloud computing. Cloud service providers are also going to be benefited in better understanding of SMEs requirements and expectations, thereby enabling them to customize their offerings accordingly. The study is expected to contribute significantly to the ever growing body of knowledge about adoption of new technologies/ innovations in organizations.

The definition provided by the Government of India is used in this study to denote SMEs. According to this definition SMEs are categorized into Micro, Small and Medium Enterprises (MSMEs) based on the investment in plant and machinery/ equipment. "Micro enterprises are defined as those manufacturing firms where investment up to ₹ 2.5 million is made (for service firms limit is ₹ 1 million); Small enterprises are categorized as firms where 
investment in plant and machinery is more than ₹ 2.5 million but not more than ₹ 50 million (for service firms investment more than ₹ 1 million and less than ₹ 20 million); Medium enterprises are defined as those firms where investment is more than ₹ 50 million but less than ₹ 100 million is made in plant and machinery (for service firms investment more than ₹ 20 million and less than ₹ 50 million)" (Kumar et al., 2017).

A review of literature is used to provide background about cloud computing and associated research. The process of developing the research framework is then described, followed with hypotheses formulation. Questionnaire design process, data collection, data analysis, hypotheses testing and the results obtained are presented in research methodology section which follows discussion about key findings. The study is concluded by highlighting managerial and research implications.

\section{Literature Review}

Cloud computing refers to delivering software and hardware resources as a service through the internet on pay-perusage basis (Armbrust et al., 2010). Using cloud computing eliminates the need for buying and maintaining complex ICT systems within the organization's premises (DeFlice, 2010). As per definition provided by NIST "cloud computing is a model for enabling ubiquitous, convenient, on-demand network access to a shared pool of configurable computing resources (e.g., networks, servers, storage, applications, and services) that can be rapidly provisioned and released with minimal management effort or service provider interaction" (Mell and Grace, 2011). Small businesses get various benefits from using cloud computing in the form of reduced entry cost for using latest ICT, reduced cycle time, lesser IT barriers to innovation (Marston et al. 2011). But, at the same time, the unique nature of cloud computing and its characteristics like online delivery of ICT resources as service, virtualization, and sharing of resources raise certain serious concerns like the security of business data, privacy protection and availability of services (Katzan, 2010; Sultan, 2011; Subashini and Kavitha, 2011; Wu, 2011).

Various authors have attempted to assess the acceptance and usage of cloud computing by organizations (Senyo et al., 2016; Gangwar et al., 2015; Gutierrez et al., 2015; Yigitbasioglu, 2015; Oliveira et al., 2014; Low et al., 2011). For this, these authors have employed different theoretical models, factors, and data analysis techniques to better understand the adoption of cloud computing at firm level.

Limited studies are found on cloud computing adoption by SMEs. TOE framework and DOI theory are used most frequently in the research on cloud computing adoption by SMEs (Alshamaila et al., 2013; Gupta et al., 2013; Makena, 2013; Carcary et al., 2014; Yeboah-Boateng and Essandoh, 2014; Abubakar et al., 2014; Abdullah and Hassan , 2015; Prasad and Green, 2015; Al-Isma'ili et al., 2016). Review of literature reveals that cloud computing adoption is explored by different authors by considering technological, organizational, and environmental perspectives along with the characteristics of innovation. Few studies are found where TAM is also used to predict cloud computing adoption by organizations (Gangwar et al., 2015; Bharadwaj and Lal, 2012).

Within the innovation characteristics, relative advantage, compatibility, and security concern are found as the major determinants of cloud computing adoption by SMEs (Alshamaila et al., 2013; Makena, 2013; Al-Isma'ili et al., 2016). Relative advantage of cloud computing for SMEs is described in the form of cost advantage, easy deployment and maintenance, improved scalability and business continuity (Alshamaila et al., 2013). Empirical evidences in the literature suggest relative advantage as a significant factor in cloud computing adoption by SMEs (Alshamaila et al., 2013; Makena, 2013; Senyo et al., 2016). 


\begin{tabular}{|c|c|c|c|c|}
\hline Author (s) & $\begin{array}{l}\text { Theoretical } \\
\text { basis }\end{array}$ & Constructs (independent variables) & Methods & $\begin{array}{l}\text { Data and } \\
\text { context }\end{array}$ \\
\hline $\begin{array}{l}\text { Alshamaila } \\
\text { et al. } \\
\text { (2013) }\end{array}$ & $\begin{array}{l}\text { TOE } \\
\text { framework }\end{array}$ & $\begin{array}{l}\text { relative advantage, uncertainty, geo- } \\
\text { restriction, compatibility, trialability, size, } \\
\text { top management support, prior } \\
\text { experience, innovativeness, industry, } \\
\text { market scope, supplier efforts and } \\
\text { external computing support }\end{array}$ & $\begin{array}{l}\text { Explorative } \\
\text { study, semi } \\
\text { structured } \\
\text { interviews, } \\
\text { qualitative } \\
\text { analysis }\end{array}$ & $\begin{array}{l}15 \text { SMEs from } \\
\text { north east of } \\
\text { England }\end{array}$ \\
\hline $\begin{array}{l}\text { Bharadwaj } \\
\text { and Lal } \\
\text { (2012) }\end{array}$ & $\begin{array}{l}\text { DOI, TAM, } \\
\text { Dynamic } \\
\text { capabilities } \\
\text { theory }\end{array}$ & $\begin{array}{l}\text { Relative advantage, perceived usefulness, } \\
\text { perceived ease of use, vendor's credibility, } \\
\text { attitude towards using technology }\end{array}$ & $\begin{array}{l}\text { Case study } \\
\text { based } \\
\text { methodology }\end{array}$ & $\begin{array}{l}10 \text { Indian } \\
\text { Organizations }\end{array}$ \\
\hline $\begin{array}{l}\text { Gupta et } \\
\text { al. (2013) }\end{array}$ & $\mathrm{DOI}$ & $\begin{array}{l}\text { ease of use and convenience, security } \\
\text { and privacy, cost reduction, reliability }\end{array}$ & SEM & $\begin{array}{l}211 \text { SMEs } \\
\text { from Asia } \\
\text { Pacific region }\end{array}$ \\
\hline $\begin{array}{l}\text { Makena } \\
\text { (2013) }\end{array}$ & $\begin{array}{l}\text { TOE } \\
\text { framework }\end{array}$ & $\begin{array}{l}\text { top management support, size, technology } \\
\text { readiness, relative advantage, } \\
\text { competitiveness, complexity and } \\
\text { compatibility }\end{array}$ & $\begin{array}{l}\text { Qualitative } \\
\text { and } \\
\text { descriptive } \\
\text { analysis }\end{array}$ & $\begin{array}{l}220 \text { ICT } \\
\text { officers from } \\
\text { Kenya }\end{array}$ \\
\hline $\begin{array}{l}\text { Carcary et } \\
\text { al. }(2014)\end{array}$ & - & $\begin{array}{l}\text { Steps in preparation of cloud adoption; } \\
\text { reasons for non-adoption; cloud adoption } \\
\text { benefits }\end{array}$ & $\begin{array}{l}\text { Explorative } \\
\text { study, } \\
\text { Descriptive } \\
\text { statistics }\end{array}$ & 95 Irish SMEs \\
\hline $\begin{array}{l}\text { Yeboah- } \\
\text { Boateng } \\
\text { and } \\
\text { Essandoh } \\
(2014)\end{array}$ & $\begin{array}{l}\text { TOE } \\
\text { framework }\end{array}$ & $\begin{array}{l}\text { Technological factors, organizational } \\
\text { factors, environmental factors }\end{array}$ & $\begin{array}{l}\text { Relative } \\
\text { importance } \\
\text { index }\end{array}$ & $\begin{array}{l}\text { ICT based } \\
\text { SMEs from } \\
\text { Ghana }\end{array}$ \\
\hline $\begin{array}{l}\text { Abubakar } \\
\text { et al. } \\
\text { (2014) }\end{array}$ & DOI & $\begin{array}{l}\text { Top management support, cost benefits, } \\
\text { security and privacy, data loss }\end{array}$ & $\begin{array}{l}\text { Qualitative } \\
\text { research }\end{array}$ & $\begin{array}{l}\text { SMEs from } \\
\text { sub-Sahara } \\
\text { African } \\
\text { Region }\end{array}$ \\
\hline $\begin{array}{l}\text { Abdullah } \\
\text { and } \\
\text { Hassan } \\
\text { (2015) }\end{array}$ & $\mathrm{DOI}$ & $\begin{array}{l}\text { Top management support, fitness of } \\
\text { cloud vendors, resistance towards } \\
\text { adopting a new technology, compatibility } \\
\text { and presence of IT Infrastructure }\end{array}$ & $\begin{array}{l}\text { Qualitative } \\
\text { research }\end{array}$ & $\begin{array}{l}\text { Secondary } \\
\text { data about } \\
\text { Iraq's SMEs }\end{array}$ \\
\hline $\begin{array}{l}\text { Prasad } \\
\text { and Green } \\
(2015)\end{array}$ & $\begin{array}{l}\text { TOE } \\
\text { framework }\end{array}$ & $\begin{array}{l}\text { Strategic and incremental intent, } \\
\text { organizational structure and culture, } \\
\text { human resource capacity, external factors }\end{array}$ & $\begin{array}{l}\text { Descriptive } \\
\text { statistics, } \\
\text { SEM }\end{array}$ & $\begin{array}{l}186 \text { Australian } \\
\text { SMEs }\end{array}$ \\
\hline $\begin{array}{l}\text { Al-Isma'ili } \\
\text { et al., } \\
\text { (2016) }\end{array}$ & $\begin{array}{l}\text { TOE } \\
\text { framework }\end{array}$ & $\begin{array}{l}\text { Technological factors, organizational } \\
\text { factors, and environmental factors }\end{array}$ & $\begin{array}{l}\text { Partial least } \\
\text { square }\end{array}$ & $\begin{array}{l}203 \text { Australian } \\
\text { SMEs }\end{array}$ \\
\hline
\end{tabular}

In the technology context, technology readiness is used as the major construct (Oliveira et al., 2014). Organizational aspects in the form of top management support and firm size are also mentioned as important factors which influence cloud computing adoption by SMEs (Abdullah and Hassan, 2015; Abubakar et al., 2014; Alshamaila et al., 2013). Top management support is found as a crucial factor that positively impact cloud computing adoption decisions among SMEs (Al-Isma'ili et al., 2016; Oliveira et al., 2014; Gangwar et al., 2015; Wang et al., 2010; Ifinedo, 2011). Environmental factors such as - external pressure and service providers' support also find mention in the literature (Abdullah and Hassan, 2015; Alshamaila et al., 2013). It is 
observed that due to the novelty and some element of uncertainty associated with cloud computing, service provider's support assumes important role in successful adoption and usage of cloud computing by SMEs (Alshamaila et al., 2013). Service provider's support is found significant factors in many studies on cloud computing and other information technology adoption by SMEs (Al-Isma'ili et al., 2016; Gangwar et al., 2015; Ramdani et al., 2009).

TAM model which is generally used to assess adoption of technology at individual level, is also used in some studies (Gangwar et al., 2015; Gupta et al., 2013; Bharadwaj and Lal, 2012). Two constructs of TAM- perceived usefulness and perceived ease of use are considered as major determinants influencing individual's intention to adopt a given technology (Davis, 1986). Perceived usefulness and perceived ease of use are reported as major constructs explaining cloud computing adoption by organizations in two studies (Gangwar et al., 2015; Bharadwaj and Lal, 2012). A summary of some of the research studies found on adoption of cloud computing in SMEs is presented in Table 1.

Dearth of studies on adoption of cloud computing by SMEs, especially in an Indian context, which are founded on strong theoretical base and which are empirically verified using powerful statistical techniques such as confirmatory factor analysis (CFA) and structural equation modelling (SEM) has been noticed in the literature review. An attempt is made in this research work to fill this research gap.

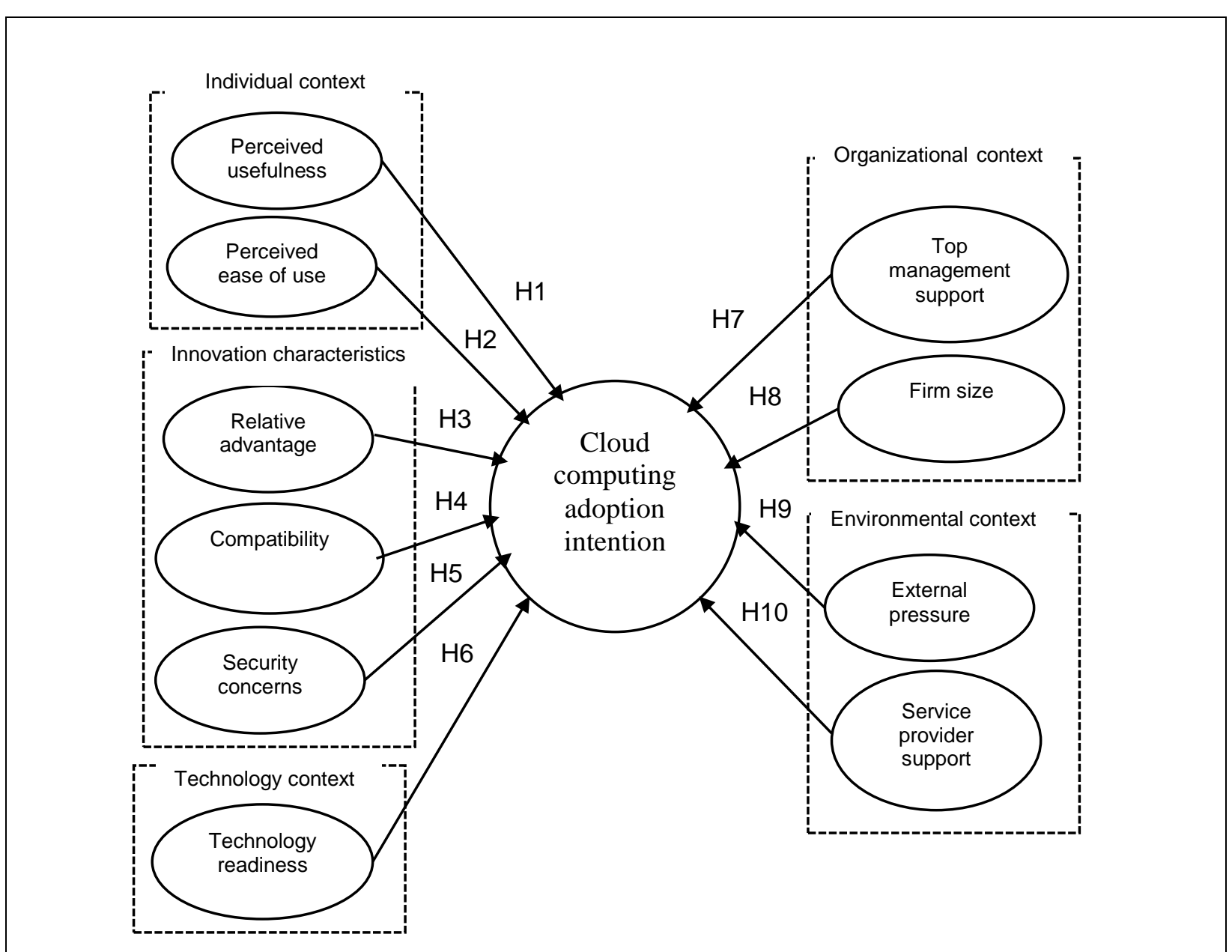

Figure 1 - Proposed research framework 


\section{Research Framework}

Ten factors described in TOE framework, DOI theory, and TAM, were found relevant for assessing the adoption of cloud computing by SMEs in the present context. The resulting model is therefore arrived at, by integrating TAM, DOI and TOE, as shown in Figure 1. The proposed model is expected to be more holistic as it combines individual perspective defined in TAM and, innovation characteristics of cloud computing as described in DOI with three perspectives provided in TOE model. The resulting framework therefore, attempts to address call by researchers for having a more universal model that enhances the understanding of diffusion of innovation in organizations (Oliveira and Martins, 2011; Oliveira et al., 2014; Wu et al., 2013).

\section{Justification for Integrating TAM, DOI and TOE Framework}

TAM, DOI and TOE framework enjoy extensive empirical support. Technology and organization perspectives of TOE framework match with some of the characteristics of new innovation given in DOI theory. TOE framework makes an extension to DOI model by adding environmental context. Many researchers have used the combination of TOE and DOI to explain cloud computing adoption at firm level (Safari et al., 2015; Oliveira et al., 2014; Low et al., 2011). However, individual perspective is also important in SME's context. SMEs are mainly driven by their owners/business partners and these people are involved in all sort of decision-making related to business. Therefore, owner's intention and attitude is equally important while investigating adoption of any new technology in SMEs. This point is also emphasized in other studies (Alam et al., 2011; Thong, 1999; Fichman and Kemerer, 1997). Individual's attitude towards adopting new information system is driven by two variables namely perceived usefulness (PU) and perceived ease of use (PEOU). This justifies inclusion of $\mathrm{PU}$ and $\mathrm{PEOU}$ in the proposed framework. Limited studies are found that have used the combination of TAM and TOE to investigate IT adoption (Alam et al., 2011; Bharadwaj and Lal, 2012; Gangwar et al., 2015). Integration of TAM, DOI and TOE is not found in the literature. This study thus attempts to propose and empirically test an integrated model which is likely to provide a clearer and improved understanding about adoption of cloud computing in SMEs. TAM constructs are used to predict SME owner's intention and attitude towards adopting cloud computing. These constructs include PU and PEOU. Two characteristics of innovation provided in DOI are found relevant in cloud computing adoption by SMEs. These are relative advantage and compatibility. Due to special nature of cloud computing, it is quite obvious to have some security concerns which may influence intention to adopt cloud computing. Therefore, security concern is also included in the innovation characteristics. Technology context from the TOE framework is used to check the technology readiness of the SME for adopting cloud computing. Organizational context investigates the role of top management and firm size in cloud adoption decisions. Environmental context describes the extent to which cloud computing adoption decisions are going to be influenced by external pressure and support provided by service providers.

\section{Hypotheses Development}

Taking clue from the prominent theories on information system adoption and the literature reviewed, ten factors were found relevant for predicting SME's intention to adopt cloud computing in the present context. Therefore, ten hypotheses concerning each factor were formulated.

\section{Perceived Usefulness}

Perceived usefulness defines prospective user's subjective probability that using a specific application will increase job related 
productivity, performance, effectiveness and/or profitability within organizational context (Davis, 1986). Here perceived usefulness specifies the degree to which users perceive that using cloud computing will increase job productivity, performance and effectiveness. Perceived usefulness associated with using cloud computing is considered as an important factor influencing intention to adopt cloud computing by organizations (Bharadwaj and Lal, 2012; Gangwar et al., 2015). The first hypothesis follows from this discussion:

H1. Perceived usefulness positively influences intention to adopt cloud computing adoption by SMEs in India.

\section{Perceived Ease of Use}

Assessing end user's efforts required in using a particular information system, is measured by a construct named perceived ease of use (Davis, 1986). The likelihood of adoption of an information system will increase if user finds it easy to use and less complex (Alam et al., 2011). In the present context perceived ease of use is the degree to which users consider that using cloud computing is easy to access, learn and utilize. If manager/owner of SME finds cloud computing easy to use and less complicated, then the chances of cloud computing adoption will increase in that SME. Perceived ease of use is used as a determinant of cloud computing adoption in other similar studies (Gangwar et al., 2015; Gupta et al., 2013; Bharadwaj and Lal, 2012). The second hypothesis follows from this discussion:

H2. Perceived ease of use positively influences intention to adopt cloud computing by SMEs in India.

\section{Relative Advantage}

Added and comparative advantages of a technology over its other substitutes assume significant role in technology adoption. Rogers (2003) defined relative advantage as "the degree to which an invention is superior over its previous generation". Cloud computing offers many unique benefits to organizations which no other computing model can provide. Relative advantage of cloud computing is manifested in the form of - flexible payment option based on usage, enhanced scalability and simpler installation and upgrade process (Geczy et al., 2012; Goodburn and Hill, 2010). Several other studies have also used relative advantage as an important factor influencing cloud computing adoption (Ghobakhloo et al., 2011; Low et al., 2011; Alshamaila et al., 2013; Oliveira et al., 2014; Senyo et al., 2016). Following hypothesis is formulated on the basis of above discussion:

H3. Relative advantage of cloud computing positively influences intention to adopt cloud computing by SMEs in India.

\section{Compatibility}

Compatibility refers to "the degree to which the innovation is perceived as consistent with potential adopter's existing values, past experiences and current needs" (Rogers 2003). The compatibility of cloud computing with the existing systems used in the organization also impacts the decision to adopt cloud computing (Oliveira et al., 2014). Close alignment of existing systems and procedures of an organization with the cloud computing leads to more benefits from adopting cloud computing and reduces uncertainties associated with cloud computing (Gangwar et al., 2015). Compatibility is reported as an important determinant of cloud based services adoption (Oliveira et al., 2014; Safari et al., 2015; Gangwar et al., 2015). So, following hypothesis is proposed:

H4. Compatibility positively influences intention to adopt cloud computing by SMEs in India.

\section{Security Concerns}

Cloud computing environment allows the sharing of computing, storage and networking infrastructure of service provider among many customers, which may raise 
certain serious security concerns (Shen and Tong, 2010; Subashini and Kavitha, 2011). The service provider is going to have access to the user's business data which may further increase the chances of security breach. The absence of strong security mechanism, policies and legal framework may hamper adoption of cloud computing by organizations. Security concern concerns are reported as major challenge in many studies on cloud computing (Al-Isma'ili et al., 2016; Safari et al., 2015; Oliveira et al., 2014). Following hypothesis is therefore proposed:

H5. Security concern concerns negatively influence SME's intention to adopt cloud computing in India.

\section{Technology Readiness}

Technological readiness is concerned with the technological infrastructure and IT human resources available within an organization. For cloud computing, the required technological infrastructure includes servers, computers, networking technologies, information systems and specialized human resources. The level of knowledge about technological innovations positively affects the likelihood of their adoption by the organizations (Ifinedo, 2011). Existence of basic ICT infrastructure along with the technical skills, are crucial for successful adoption of cloud computing in organizations. (Low et al., 2011). Therefore, the firms having sufficient technological readiness are more prepared towards cloud computing adoption. Therefore, following hypothesis is proposed:

H6. Technological readiness positively influences intention to adopt cloud computing by SMEs in India.

\section{Top Management Support}

Top management support is recognized as an important factor in IT adoption literature. Infinedo (2011) explains it as the top management's involvement, motivation and commitment towards adoption of information systems. Top management support and commitment confirms adequate supply of resources required for implementing a new technology and helps in building a congenial organizational environment for adopting that technology by employees (Pan and Jang, 2008; Wang et al., 2010). In Indian SME's context, where generally a simple and flat organizational structure is followed, top management refers to the owner of the SME unit. Owner of the SME unit is the head of all the functions and is the final decision maker. Therefore, if owner of the SME perceives cloud computing beneficial for the firm and easy to implement then the chances of its adoption increase significantly. So, the following hypothesis is proposed:

H7. Top management support positively influences intention to adopt cloud computing by SMEs in India.

\section{Firm Size}

Size of the firm plays an important role in influencing firm's intention to adopt technology (Rogers, 2003; Tornatzky and Fleisher, 1990). Large firms have more resources, greater economy of scale and have more risk taking capacity associated with technology adoption. Small firms on the other hand do not readily adopt new technologies mainly because of resource constraints. However, small firms are considered more agile and flexible (Lippert and Govindarajulu, 2006). Within SME, there are three types of enterprises namely micro, small and medium. Therefore, size of SME in terms of number of employees and investment made in plant and machinery, is going to be an important factor in cloud computing adoption decision. Hence, following hypothesis is proposed:

H8. Firm size positively influences SME's intention to adopt cloud computing in India.

\section{External Pressure}

The extent to which an organization is influenced by external sources, is recognized as an important factor influencing adoption of information 
technology innovations. External pressure is one of such factor that refers to the influences that an organization receives from three main sources that includecompetitive pressure, supplier's pressure and customer's pressure (Hart and Saunders, 1997; Chau and Jim, 2002; Kula and Tatoglu, 2003; Chong et al., 2009). Adoption of a new technology in an organization is significantly influenced by external pressure particularly when this technology directly affects the competition and is a strategic necessity (Oliveira et al., 2014). These observation are equally applicable in cloud computing context. The ninth hypothesis follows from this discussion:

H9. External pressure positively influences intention to adopt cloud computing by SMEs in India.

\section{Service Provider Support}

In cloud computing environment, the firms will get computing resources as a service from the service providers, on-demand and on pay-per-usage basis. The firms thus have to rely on the service providers for all those services which are migrated to the cloud. Therefore, cloud service provider's reputation, reliability and support become very crucial for uninterrupted and secure availability of cloud services. Being a new technology, the support from cloud provider's side assumes an important role in making a constructive effect on SME's intent towards using cloud computing. Service provider's support is also recognized as an important factor in cloud computing adoption by firms in other similar studies (Al-Isma'ili et al., 2016; Gangwar et al., 2015). So, the following hypothesis is proposed:

H10. Service providers' support positively influences intention to adopt cloud computing by SMEs in India.

\section{Research Methodology}

Considering very limited research on cloud computing adoption by SMEs, especially in an Indian context, explorative study is most reasonable (Zikmund et al., 2010). A positivism research approach is believed suitable, keeping in view, the aim of this study, which is to make contribution towards growing body of knowledge on the adoption of new information technology like cloud computing in organizations by formulating and quantitatively testing a conceptual framework (Cohen et al., 2011). In the research on the diffusion and adoption of innovation, quantitative approaches which are founded on questionnaire based survey, are the most prevalent research methodologies (Wang et al., 2011). Therefore, a quantitative, cross sectional, and questionnaire based survey methodology was employed in this study.

\section{Measurement}

This study is aimed at evaluating determinants of cloud computing adoption by SMEs in India using a framework based on TAM, DOI and TOE. For this, a questionnaire based survey method was followed to collect data from manufacturing SMEs in India. The factors and items used in the questionnaire were based on the published literature as shown in Table 2 . The questionnaire comprised of three parts: organizational profile, adoption variables and personal detail of the respondent. The constructs used in the study were quantified by a Likert-type scale using multiple-items and five point scale ranging from 1 (strongly disagree) to 5 (strongly agree). Total investment in plant and machinery and number of employee working in the organization are used as a measure of firm size (Oliveira et al., 2014; Zhu et al., 2006). All questionnaire items and sources are presented in Appendix I. The questionnaire was reviewed by the academic researchers and subsequently pilot tested on some known SMEs. The results provided 
evidence that questions are understandable and scales are reliable.

\begin{tabular}{|c|c|}
\hline Variable & Source(s) \\
\hline Perceived usefulness & Gangwar et al. (2015), Wu(2011); Grandon and Pearson(2004) \\
\hline Perceived ease of use & Gangwar et al. (2015), Gupta et al. (2013); Alam et al. (2011); \\
\hline Relative advantage & $\begin{array}{l}\text { Al-Isma'ili et al. (2016); Oliveira et al. (2014); Safari et al. (2015); Geczy } \\
\text { et al. (2012); Alam et al.(2011); Wang et al. (2010) }\end{array}$ \\
\hline Compatibility & $\begin{array}{l}\text { Al-Isma'ili et al. (2016); Oliveira et al. (2014), Alshamaila et al. (2013); } \\
\text { Wang et al. (2010) }\end{array}$ \\
\hline Security and privacy & $\begin{array}{l}\text { Oliveira et al. (2014), Safari et al. (2015); Gupta et al. (2013); Wu(2011); } \\
\text { Alam et al. (2011) }\end{array}$ \\
\hline Technology readiness & Oliveira et al. (2014); Wu (2011); Wang et al. (2010) \\
\hline Top management support & $\begin{array}{l}\text { Al-Isma'ili et al. (2016); Oliveira et al. (2014), Gangwar et al. (2015), } \\
\text { Wang et al. (2010), Ifinedo (2011) }\end{array}$ \\
\hline Firm size & Oliveira et al. (2014); Alshamaila et al. (2013); Low et al. (2011) \\
\hline External pressure & Oliveira et al. (2014); Alshamaila et al. (2013); Ifinedo (2011), \\
\hline Service provider support & $\begin{array}{l}\text { Al-Isma'ili et al. (2016); Gangwar et al. (2015); Alshamaila et al. (2013); } \\
\text { Ifinedo (2011) }\end{array}$ \\
\hline Adoption intention & Gangwar et al. (2015); Wu(2011) \\
\hline
\end{tabular}

\section{Data}

The SMEs selected for the survey comprised of those enterprises which were members of Confederation of Indian Industries (CII), Chandigarh. The reason for choosing this database was that the member firms were expected to be aware about importance of ICT and latest technological innovations such as cloud computing through various training programs/workshops/seminars organized by Cll for its members on technological interventions for enhancing SME competitiveness. The MSMEs selected were mainly from three northern states of India - Himachal Pradesh, Punjab and Haryana. The respondents were mostly owner/partners of the SMEs. The potential respondents were initially contacted through e-mail and telephone and certain screening questions were asked to check their suitability for the survey. Regular training programs/seminars/workshops organized by Cll were also utilized as a platform to directly communicate with the owners/managers of the SMEs wherein they were briefed about the survey and appropriate time was fixed for further data collection from those SMEs which were found suitable for survey. A total of 565 SMEs were thus screened for data collection and questionnaire were distributed to them. Most of the responses were collected through personal visits. Other responses were collected through emails. A total of 271 valid responses were finally collected with a response rate of 47.96 percent.

\section{Data Analysis}

Data collected from 271 SMEs was analyzed with the help of IBM SPSS Statistics 20 and IBM SPSS Amos 21.0. The characteristics of the data collected from the SMEs were analyzed to understand the respondent's profile. Reliability of the scale was tested by calculating Cronbach's alpha for each of the factor. Confirmatory factor analysis was used to confirm the factor structure and to check construct validity. Structural equation modeling was further used to specify and assess the validity of structural model and for testing the hypotheses. 


\section{Sample Characteristics}

The respondent $(\mathrm{N}=271)$ included micro enterprises $(n=85)$, small enterprises $(n=90)$ and medium enterprises $(n=96)$. Mainly the manufacturing SMEs were covered in the survey and the type of industries to which these SMEs belong, is mentioned in the sample characteristics. Other characteristics of these SMEs like number of employees, annual turnover, type of industry and their clientele is also provided in Table 3. Majority of SMEs $(61 \%)$ are planning to adopt cloud computing in next 2-3 years. Around $80 \%$ of the SMEs preferred SaaS over other types of cloud services.

\begin{tabular}{|c|c|c|}
\hline Characteristics & Number & Percentage \\
\hline $\begin{array}{l}\text { Organization type } \\
\text { Micro Enterprise } \\
\text { Small Enterprise } \\
\text { Medium Enterprise }\end{array}$ & $\begin{array}{l}85 \\
90 \\
96\end{array}$ & $\begin{array}{l}31.4 \\
33.2 \\
35.4\end{array}$ \\
\hline $\begin{array}{l}\text { Type of industry } \\
\text { Auto components } \\
\text { Metal products } \\
\text { Pharmaceutical and biotech } \\
\text { Packaging } \\
\text { Food and agro products } \\
\text { Basic chemical and chemical products } \\
\text { Scientific instruments } \\
\text { Engineering, electrical and electronics } \\
\text { Others }\end{array}$ & $\begin{array}{l}25 \\
10 \\
23 \\
10 \\
10 \\
11 \\
3 \\
60 \\
119\end{array}$ & $\begin{array}{l}9.2 \\
3.7 \\
8.5 \\
3.7 \\
3.7 \\
4.1 \\
1.1 \\
22.1 \\
43.9\end{array}$ \\
\hline $\begin{array}{l}\text { Total number of employees } \\
\text { Less than } 25 \\
\text { Between } 25-50 \\
\text { Between } 51-75 \\
\text { Between } 76-100 \\
\text { More than } 100\end{array}$ & $\begin{array}{l}82 \\
56 \\
52 \\
36 \\
45\end{array}$ & $\begin{array}{l}30.3 \\
20.7 \\
19.2 \\
13.3 \\
16.6\end{array}$ \\
\hline $\begin{array}{l}\text { Organization's annual turnover } \\
\text { Up to Rs. } 5 \text { Million } \\
\text { Above Rs. } 5 \text { million and up to Rs. } 10 \text { million } \\
\text { Above Rs. } 10 \text { million and up to Rs. } 50 \text { million } \\
\text { Above Rs. } 50 \text { million and up to Rs. } 100 \text { million } \\
\text { Above Rs. } 100 \text { million }\end{array}$ & $\begin{array}{l}64 \\
68 \\
62 \\
48 \\
29\end{array}$ & $\begin{array}{l}23.6 \\
25.1 \\
22.9 \\
17.7 \\
10.7\end{array}$ \\
\hline $\begin{array}{l}\text { Plan to adopt cloud computing } \\
\text { Already adopted cloud computing } \\
\text { Using cloud computing on trial basis } \\
\text { Planning to use cloud computing in next 2-3 years } \\
\text { Not planning to use cloud computing in near future }\end{array}$ & $\begin{array}{l}47 \\
22 \\
166 \\
36\end{array}$ & $\begin{array}{l}17.3 \\
8.1 \\
61.3 \\
13.3\end{array}$ \\
\hline $\begin{array}{l}\text { Type of cloud service preferred } \\
\text { Individual software packages (SaaS) } \\
\text { Infrastructure services (laaS) } \\
\text { System software as service (PaaS) } \\
\text { Security services } \\
\text { Combination of above services }\end{array}$ & $\begin{array}{l}218 \\
3 \\
22 \\
3 \\
25\end{array}$ & $\begin{array}{l}80.4 \\
1.1 \\
8.1 \\
1.1 \\
9.2\end{array}$ \\
\hline
\end{tabular}




\section{Reliability Analysis}

Cronbach's a value of 0.937 is revealed in reliability analysis which is in line with the reliability reported in other studies. The principal component analysis method and varimax rotation were employed to factor analyse the scale. The value of measures used for testing sampling adequacy and sphericity were found to be significant with Kaiser-Meyer-Olkin value of 0.914 . This value confirms sampling adequacy and ensure factorability of the data.

The reliability of the subscale varied from 0.747 and 0.910 which greatly exceeded the recommended value of 0.50 (Hair et al., 1992). The variables were grouped into eleven factors, and all these accounted for 73.704 percent of the total variance. This value implies that the set of factors extracted from the data explains great extent of adoption intention and very less portion of the adoption intention remains unexplained.

\section{Confirmatory Factor Analysis}

Stability of the scale was tested using structural equation modelling by employing confirmatory factor analysis. Measurement model was developed using IBM SPSS Amos 21.0. For performing confirmatory factor analysis, Maximum Likelihood method was selected. To assess the model fit, a variety of indices were used (Table 4). The analysis of data established largely reasonable level of fit for the indices likechi-square value divided by the degrees of freedom $\left(X^{2} / D F\right)$, the root mean square error of approximation (RMSEA), and the comparative fit index (CFI) as recommended by Hair et al. (1992). The CMIN/DF (chi-square/df) was obtained as 1.642 which is below the recommended level of absolute 5 . The CFI obtained was 0.940 , which is above the recommended level of 0.9 . The RMSEA obtained was 0.04 , which is less than the recommended level of 0.05 . This reflects a good model fit. These results confirm that the items describe their corresponding factors in a reasonable manner. The goodness-of-fit Index (GFI) and adjusted goodness-of-fit Index (AGFI) were obtained as 0.839 and 0.806 respectively. The value of Tucker-Lewis index (TLI) was found to be 0.931 , which is greater than the acceptable level of 0.90 . Incremental fit index (IFI) was obtained as 0.940 which is also more than the acceptable level of 0.90 . Thus the 10 factor model with a Chi-square statistic of 1062.217 had a good overall fit to the data.

\section{Table 4 - Goodness-of-fit statistics for the measurement model}

\begin{tabular}{|l|l|l|}
\hline Measurement indices & Model Value & Recommended value \\
\hline Chi-Square $\left(\mathrm{X}^{2}\right) /$ Degree of freedom(DF) & $1062.217 / 647=1.642$ & $\leq 3.000$ \\
\hline Comparative Fit Index (CFI) & 0.940 & $\geq 0.9000$ \\
\hline Goodness of Fit Index (GFI) & 0.839 & $\geq 0.9000$ \\
\hline Adjusted Goodness of Fit Index (AGFI) & 0.806 & $\geq 0.8000$ \\
\hline Root Mean Square Error Approximation (RMSEA) & 0.049 & $\leq 0.05$ \\
\hline Tucker-Lewis Index (TLI) & 0.931 & $\geq 0.9000$ \\
\hline Incremental Fit Index (IFI) & 0.940 & $\geq 0.9000$ \\
\hline
\end{tabular}

The convergent and discriminant validity of the scales using confirmatory factor analysis was further tested. Two tests namelycomposite reliabilities and average variance extracted, suggested by Anderson and Gerbing (1988) were used for testing convergent validity as shown in Table 5 . Composite reliabilities (CRs) were found 
above the threshold of 0.70 in each instance (Hair et al. 1992). The values for average variance extracted (AVE) were found in the range of 0.50 to 0.78 for all of the constructs.
These estimates are found above or equal to the minimum level of 0.50 (Fornell and Larcker, 1981). The results thus established the convergent validity of the scales.

\section{Table 5 - Confirmatory factor analysis (CFA) results}

\begin{tabular}{|l|l|l|}
\hline Measure & CR & AVE \\
\hline Service provider support (SPS) & 0.752 & 0.505 \\
\hline Perceived usefulness (PU) & 0.886 & 0.661 \\
\hline Perceived ease of use (PEOU) & 0.882 & 0.654 \\
\hline Relative advantage (RA) & 0.838 & 0.513 \\
\hline Compatibility (COMP) & 0.869 & 0.627 \\
\hline Security concerns (SC) & 0.873 & 0.697 \\
\hline Top management support (TMS) & 0.915 & 0.731 \\
\hline Firm size (FS) & 0.916 & 0.783 \\
\hline Technology readiness (TR) & 0.879 & 0.646 \\
\hline External pressure (EP) & 0.811 & 0.683 \\
\hline Cloud computing adoption (CCA) & 0.870 & 0.693 \\
\hline CR: Composite Reliability, AVE: Average Variance extracted & \\
\hline
\end{tabular}

Tests suggested by Anderson and Gerbing (1988) were used to check the discriminant validity. To qualify this test, factor correlation among a pair of latent variables should be less than the square root of AVE of each variable as shown in Table 6 by factor correlation matrix. The examination of this validity test indicates that the square root of AVE of each variable shown in bold across the diagonal of Table 6 is greater than the correlation value of each pair of variable. The results of this test show that each construct nominated in this study is different from other. Hence, discriminant validity of the scale is confirmed.

\section{Table 6 - Factor correlation matrix}

\begin{tabular}{|l|c|c|c|c|c|c|c|c|c|c|c|}
\hline Variable & SPS & PU & PEOU & RA & COMP & SC & TMS & FS & TR & EP & CCA \\
\hline SPS & $\mathbf{0 . 7 1 0}$ & & & & & & & & & & \\
\hline PU & 0.320 & $\mathbf{0 . 8 1 3}$ & & & & & & & & & \\
\hline PEOU & 0.373 & 0.535 & $\mathbf{0 . 8 0 9}$ & & & & & & & & \\
\hline RA & 0.461 & 0.686 & 0.542 & $\mathbf{0 . 7 1 6}$ & & & & & & & \\
\hline COMP & 0.379 & 0.447 & 0.582 & 0.477 & $\mathbf{0 . 7 9 2}$ & & & & & & \\
\hline SC & 0.188 & 0.472 & 0.275 & 0.315 & 0.318 & $\mathbf{0 . 8 3 5}$ & & & & & \\
\hline TMS & 0.385 & 0.578 & 0.588 & 0.599 & 0.533 & 0.264 & $\mathbf{0 . 8 5 5}$ & & & & \\
\hline FS & 0.227 & 0.007 & -0.015 & 0.057 & -0.031 & -0.043 & 0.029 & $\mathbf{0 . 8 8 5}$ & & & \\
\hline TR & 0.483 & 0.511 & 0.629 & 0.546 & 0.592 & 0.337 & 0.670 & -0.011 & $\mathbf{0 . 8 0 4}$ & & \\
\hline EP & 0.222 & 0.593 & 0.611 & 0.529 & 0.664 & 0.418 & 0.587 & -0.092 & 0.689 & $\mathbf{0 . 8 2 7}$ & \\
\hline CCA & 0.592 & 0.450 & 0.548 & 0.599 & 0.501 & 0.169 & 0.612 & -0.005 & 0.629 & 0.678 & $\mathbf{0 . 8 3 3}$ \\
\hline SPS: SeV & & & & & & & & & \\
\hline
\end{tabular}

SPS: Service provider's support, PU: Perceived usefulness, PEOU: Perceived ease of use, RA: Relative advantage, COMPT: Compatibility, SC: Security concerns, TMS: Top management support; FS: Firm size; TR: Technology readiness, EP: External pressure; CCA: Cloud computing adoption 


\section{Structural Equation Modelling (Hypotheses Testing)}

The measurement model was converted to structural model to test the proposed hypotheses. The simplified structural model is shown in Figure 2. The hypotheses proposed were tested using standardized regression weight estimates, the critical ratio (CR) and $p$-value, as shown in Table 7.

Out of ten hypotheses proposed, five were found significant. Among the innovation characteristics, two hypotheses concerning relative advantage and security and privacy were supported. Relative advantage was found to positively influence cloud computing adoption intention by SMEs (H3) $(p<0.01)$. Security concerns were found to have a negative impact on intention to adopt cloud computing by SMEs (H5) $(\mathrm{p}<0.05)$.
Top management support in the organizational context was found significant and had positive influence on SMEs intention to adopt cloud computing $(\mathrm{H} 7)(\mathrm{p}<$ 0.001). Both of the factors under environmental context, which are - external pressure and service provider support, were found significant. External pressure was found to positively influence SMEs intention to adopt cloud computing (H9) $(p<0.001)$. Similarly, service provider support $(\mathrm{H} 10)$ was found statistically significant $(p<0.001)$. The hypotheses for perceived usefulness $(\mathrm{H} 1)$, perceived ease of use $(\mathrm{H} 2)$, compatibility $(\mathrm{H} 4)$, technology readiness $(\mathrm{H} 6)$ and firm size (H8) were not found statistically significant. The research model explained 55 percent of cloud computing adoption intention by SMEs.

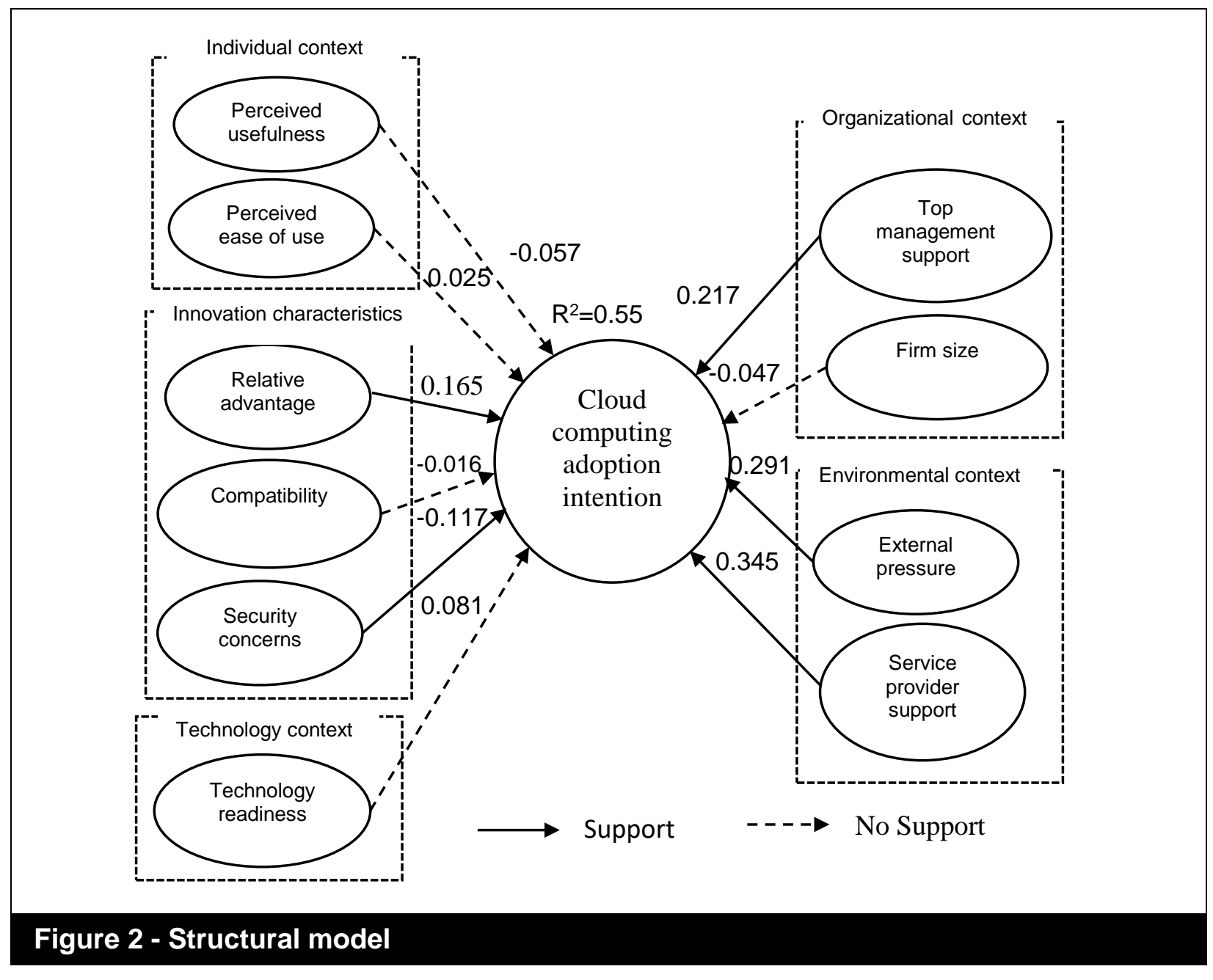




\begin{tabular}{|c|c|c|c|c|c|}
\hline $\begin{array}{l}\text { SI. } \\
\text { no. }\end{array}$ & Path & $\begin{array}{c}\text { Standardized } \\
\text { path } \\
\text { coefficients }\end{array}$ & CR & p-value & Result \\
\hline $\mathrm{H} 1$ & $\begin{array}{llll}\begin{array}{l}\text { Perceived } \\
\text { intention }\end{array} & \text { usefulness } & \rightarrow & \text { Adoption } \\
\end{array}$ & -0.057 & -0.973 & 0.33 & Not supported \\
\hline $\mathrm{H} 2$ & $\begin{array}{l}\text { Perceived ease of use } \rightarrow \text { Adoption } \\
\text { intention }\end{array}$ & 0.025 & 0.456 & 0.648 & Not supported \\
\hline $\mathrm{H} 3$ & $\begin{array}{llll}\begin{array}{l}\text { Relative } \\
\text { intention }\end{array} & \text { advantage } & \rightarrow & \text { Adoption }\end{array}$ & 0.165 & 2.905 & 0.004 & Supported \\
\hline $\mathrm{H} 4$ & Compatibility $\rightarrow$ Adoption intention & -0.016 & -0.302 & 0.763 & Not supported \\
\hline $\mathrm{H} 5$ & Security concerns $\rightarrow$ Adoption intention & -0.117 & -2.472 & 0.013 & Supported \\
\hline $\mathrm{H} 6$ & $\begin{array}{lll}\text { Technology } & \text { readiness } \rightarrow & \text { Adoption } \\
\text { intention } & & \end{array}$ & 0.081 & 1.35 & 0.177 & Not supported \\
\hline $\mathrm{H} 7$ & $\begin{array}{l}\text { Top management support } \rightarrow \text { Adoption } \\
\text { intention }\end{array}$ & 0.217 & 3.752 & $\star * * *$ & Supported \\
\hline $\mathrm{H} 8$ & Firm size $\rightarrow$ Adoption intention & -0.047 & -1.108 & 0.268 & Not supported \\
\hline $\mathrm{H} 9$ & External pressure $\rightarrow$ Adoption intention & 0.291 & 5.854 & $* * \star$ & Supported \\
\hline $\mathrm{H} 10$ & $\begin{array}{l}\text { Service providers support } \rightarrow \text { Adoption } \\
\text { intention }\end{array}$ & 0.345 & 6.054 & 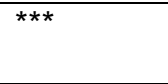 & Supported \\
\hline
\end{tabular}

\section{Discussion}

This study was aimed at assessing the factors that persuade cloud computing adoption by SMEs by making use of a proposed integrated framework founded on TAM, DOI, and TOE framework. The results indicated that factors persuading the adoption of cloud computing among SMEs include relative advantage, security concern, top management support, external pressure and service providers' support.

Innovation characteristics: Out of three hypothesized characteristics of innovation, two are found statistically significant, which include relative advantage $(\mathrm{H} 3)$ and security concerns ( $\mathrm{H} 5)$. The findings indicate that the relative advantages of cloud computing has a positive impact on the intention to adopt cloud computing by SMEs. Relative advantages of clouds computing identified in this study include flexible and use based payment options, cost benefits, enhanced scalability, and simpler set-up and upgrade process. This finding is consistent with similar studies found in literature (Oliveira et al., 2014; Gangwar et al., 2015; Infinedo, 2011). Security concerns (H5) emerged as a significant issue for SMEs. It is revealed in this study that security concerns negatively influence SME's intention to adopt cloud computing. This means that SMEs are apprehensive about the security mechanism built in the cloud computing environment and therefore, SMEs feel reluctant in migrating their data onto the cloud. Similar results are reported in other studies on cloud computing adoption (Yeboah-Boateng and Essandoh, 2014; Gupta et al., 2013). Compatibility $(\mathrm{H} 4)$ is not found significant in influencing SME's intention to adopt cloud computing. This may be attributed to the fact that cloud computing does not require special kind of software and hardware as it can be implemented with existing ICT infrastructure which is commonly found among all organizations. Therefore, compatibility may not be a significant issue for the SMEs for adopting cloud computing. Compatibility is also not found significant in other studies (Low et al., 2011; Borgman et al., 2013).

Technology context: Technology readiness (H6) was hypothesized as a facilitator of cloud computing adoption in SMEs. Technology readiness is revealed as an insignificant factor and therefore, may not influence SME's intention to use cloud 
computing. This may be attributed due to lack of awareness about cloud computing among SMEs and non-availability of IT specialists in the SMEs. Technology readiness is found non-significant in other similar studies (Low et al., 2011, Wu et al., 2013)

Organizational context: Of the two constructs hypothesized under the organizational context, only one is found statistically significant. This study confirms that support provided by the top management $(\mathrm{H} 7)$ plays an important role in influencing intention to adopt cloud computing by SMEs. This factor assumes more importance in case of Indian SMEs where top management usually comprises owners of the SMEs only, and their perception about any innovation such as cloud computing is likely going to influence its adoption in the organization. Similar results are reported in other studies (Low et al., 2011; Infinedo, 2011; Alshamaila et al., 2013). Firm size (H8) is not found important. This may be credited to the point that smaller firms are more flexible and thus are more ready to adopt cloud computing. Large number of employees and higher turnover therefore, do not reflect more inclination towards adopting cloud computing. Negative path coefficient value $(-0.047)$ from firm size to adoption further suggests that firm size is negatively related to cloud computing adoption. Similar results are obtained in a study by Borgman et al. (2013).

Environmental context: Both of the variables in environmental context - external pressure and service providers' support, were found significant in influencing SME's intention to adopt cloud computing. Findings reveal that external pressure $(\mathrm{H} 9)$ has a positive impact on the intention to adopt cloud computing by SMEs. This means that pressure exerted by competitors, suppliers, and other business partners influences decision to adopt cloud computing. Similar results are reported in other studies (Gangwar et al., 2015; Low et al., 2011; Infinedo, 2011). Service providers support $(\mathrm{H} 10)$ is also revealed as a significant factor influencing intention to adopt cloud computing by SMEs. Being a new technology, SMEs will rely more on service providers' support for the uninterrupted availability of cloud services. Gangwar et al. (2015) have reported similar results, and they have termed it as trading partner support. Alshamaila et al., (2013) have also found service provider support as a significant determinant of cloud computing adoption.

Individual context: Both of the variables in the individual context (perceived usefulness and perceived ease of use) are found nonsignificant in influencing intention to adopt cloud computing by SMEs. This may be attributed to the fact that cloud computing, as such is not a new information system. Enterprises are already using different ICTs in running their businesses, and cloud computing is only a new and innovative way to deliver various kind of ICTs to customers in a cost effective manner. Therefore, perceived usefulness regarding system usage might not be that relevant in the present context. Same is the case with perceived ease of use. Organizations are already using information systems, and employees are well versed in using these systems. Cloud computing is only going to bring a minor change in the manner in which the ICTs are accessed. Therefore, the idea of evaluating perceived ease of use of cloud computing might not be relevant for the SMEs. Alam et al., (2011) have reported similar results for perceived ease of use in a study on e-commerce adoption among SMEs in Malaysia.

\section{Implications}

\section{Managerial and Practical Implications}

Outcomes of this research show that relative advantage, security concerns, top management support, external pressure and service providers' support influence intention to adopt cloud computing by SMEs. The findings may help SMEs in evaluating 
their readiness for adopting cloud computing by carefully examining the factors identified. The first factor that managers in SMEs consider important while planning to adopt cloud computing is the relative advantage of this innovation in the form of cost benefits, scalability, ease in installation and maintenance, improved back-up and easier access to latest IT. Therefore managers in SMEs will plan to adopt cloud computing only if they find it relatively advantageous. Security concern concerns emerge as a serious challenge for SMEs. Managers in SMEs are not fully convinced about security concern protection in cloud computing environment. The service providers need to educate organizations about the security mechanisms implemented in cloud computing to win their confidence. The awareness and understanding among SMEs about security procedures and policies used by service providers will make a positive impact on SME's intention to adopt cloud computing. Top management support is equally important in making a positive impact on SME's intention to adopt cloud computing. Top management in SMEs in India mostly comprises owners and, all decision making is done by them only. If they are aware of the benefits of latest technological developments for their businesses, then they are certainly going to provide support and release necessary resources to adopt that technology. External pressure from competitors and business partners is also an important factor influencing SMEs intention to adopt cloud computing. SMEs are looking for ways and means to make their processes more efficient and increase their market reach to become more competitive. This is possible by utilizing latest ICTs, and cloud computing has the potential to make this possible at minimum cost. Cloud computing is still in nascent stage, and SMEs are not fully aware of operational issues involved in its adoption. Therefore SMEs need more hand holding and support in the initial phases. Service providers support thus becomes very crucial for successful adoption of cloud computing. With service provider's active support, SMEs can fully utilize cloud computing for the improvement their businesses and can also manage other challenges like security concerns in a better way.

\section{Implication for Theory}

Many researchers have called for joining various theoretical models to enhance understanding about the adoption of different pioneering technologies in organizations. This study makes a significant contribution towards enrichment of body of knowledge related to the adoption of new technologies like cloud computing among organizations, especially in small businesses. Three theoretical models (TAM, DOI and TOE) are integrated into the present study to strengthen the predictive power of the resulting model. The model combines individual context (perceived usefulness and perceived ease of use from SME owner's perspective) and innovation characteristics (relative advantage, compatibility, security concern) with three contexts of TOE framework (technological, organizational and Environmental). The instrument developed based on this model is confirmed for reliability, validity and discriminant checks. The application of SEM (considered as a statistically powerful technique) further confirms a good model fit. The study, therefore, is not only novel in many ways but also intends to address research gaps identified in previous studies (Al-Isma'ili et al., 2016; Oliveira et al., 2014; Alshamaila et al., 2013)

\section{Conclusion}

Cloud computing holds huge potential to increase ICT penetration among organizations in the most cost effective way. Through cloud computing, SMEs can get access to relevant ICTs in a secure, costeffective and convenient manner, which will help them to compete and grow. This study 
attempts to evaluate contributing factors concerning adoption of cloud computing among SMEs in the India. Three theoretical perspectives are integrated into this study to arrive at a research framework, which is further empirically tested with data from 271 SMEs in India. Ten hypotheses were proposed based on the literature review. Five hypotheses were supported. The results confirm that relative advantage, security concerns, top management support, external pressure and service providers' support are significant factors of cloud computing adoption by SMEs. One important challenge is also highlighted in this study which is related to security concerns arising in cloud computing adoption. The study is thus, a distinct attempt and important contribution towards understanding the adoption of innovations like cloud computing among SMEs.

This study is not without some limitations. Some additional variables relevant to the cloud computing, and context of the study can be considered. SMEs covered in the survey are mostly manufacturing firms and all are from one region of the country. Other variables can be included in the future studies, and SMEs from other areas can also be included. Industry-wise adoption can also be attempted.

\section{References}

Abdullah, I., and Hassan, Z. (2015). "A cloud technology migration management strategy model for SMEs in Iraq: An overview," Journal of Theoretical and Applied Information Technology, 73(3), pp. 354-367.

Abubakar, A. D., Bass, J. M., and Allison, I. (2014). "Cloud computing: Adoption issues for Sub-Saharan African SMEs," EJISDC, 62(1), pp. 1-17.
Alam, S. S., Ali, M. Y., and Jani, M. F. M. (2011). "An empirical study of factors affecting electronic commerce adoption among SMEs in Malaysia," Journal of Business Economics and Management,12(2), pp. 375-399.

Al-Isma'ili, S., Li, M., Shen, J. and He, Q. (2016). "Cloud computing adoption determinants: An analysis of Australian SMEs," In Pacific Asia Conference on Information Systems 2016 Proceedings., United States: AIS Electronic Library, pp. 1-17.

Alshamaila, Y., Papagiannidis, S., and Li, F. (2013). "Cloud computing adoption by SMEs in the north east of England: A multi-perspective framework," Journal of Enterprise Information Management, 26(3), pp. 250-275.

Anderson, J. C., and Gerbing, D. W. (1988). "Structural equation modelling in practice: A review and recommended two-step approach" Psychological bulletin, 103(3), p. 411.

Armbrust, M., Fox, A., Griffith, R., Joseph, A. D., Katz, R., Konwinski, A., Lee, G., Patterson, D., Rabkin, A., Stoica, I. and Zaharia, M. (2010). "A view of cloud computing-clearing the clouds away from the true potential and obstacles posed by this computing capability," Communications of the ACM, 53(4), pp. 50-58.

Bharadwaj, S. S., and Lal, P. (2012). "Exploring the impact of Cloud Computing adoption on organizational flexibility: A client perspective," In Cloud Computing Technologies, Applications and Management (ICCC TAM), International Conference on 2012 Dec 8 (pp. 121-131). IEEE.

Bhat, J. M. (2013). "Adoption of cloud computing by SMEs in India: a study of the institutional factors," In the proceedings of the Nineteenth Americas Conference on Information Systems, Chicago, Illinois, August 1517, 2013. 
Borgman, H. P., Bahli, B., Heier, H., and Schewski, F. (2013). "Cloudrise: exploring cloud computing adoption and governance with the TOE framework," In System Sciences (HICSS), 2013 46th Hawaii International Conference on (pp. 4425-4435). IEEE.

Carcary, M., Doherty, E. and Conway, G. (2014). "The adoption of cloud computing by Irish SMEs-An exploratory study," Electronic Journal Information Systems Evaluation Volume, 17(1), pp. 1-14.

Chau, P. Y., and Jim, C. C. (2002). "Adoption of electronic data interchange in small and mediumsized enterprises," Journal of Global Information Management (JGIM), 10(4), pp. 61-85.

Chong, A. Y. L., Lin, B., Ooi, K. B., and Raman, M. (2009). "Factors affecting the adoption level of c-commerce: An empirical study," Journal of Computer Information Systems, 50(2), pp.13-22.

Cohen, L., Manion, L. and Morrison, K. (2011). Research Methods in Education. Taylor and Francis.

Davis, F. D. (1986). "A technology acceptance model for empirically testing new end-user information systems: Theory and results," Doctoral dissertation, Massachusetts Institute of Technology, Massachusetts Ave, Cambridge, MA, USA.

DeFlice, A. (2010). "Cloud computing: What accountants need to know," Journal of Accountancy, 210(4), pp. 50-55.

Fichman, R. G. and Kemerer, C. F. (1997). "The assimilation of software process innovations: An organizational learning perspective," Management Science, 43(10), pp. 1345-1363.
Fornell, C., and Larcker, D. F. (1981). "Evaluating structural equation models with unobservable variables and measurement error," Journal of Marketing Research, 18(1), pp. 39-50.

Gangwar, H., Date, H., and Ramaswamy, R. (2015). "Understanding determinants of cloud computing adoption using an integrated TAM-TOE model," Journal of Enterprise Information Management, 28(1), pp. 107-130.

Geczy, P., Izumi, N., and Hasida, K. (2012). "Cloudsourcing: Managing cloud adoption," Global journal of Business Research, 6(2), pp. 57-70.

Ghobakhloo, M., Arias-Aranda, D., and Benitez-Amado, J. (2011). "Adoption of e-commerce applications in SMEs," Industrial Management and Data Systems, 111(8), pp. 1238-1269.

Goodburn, M. A. and Hill, S. (2010). "The cloud transforms businesses" Financial Executive, 26(10), pp. 34-40.

Grandon, E. E., and Pearson, J. M. (2004). "Electronic commerce adoption: an empirical study of small and medium US businesses," Information and management, 42(1), pp.197-216.

Gupta, P., Seetharaman, A., and Raj, J. R. (2013). "The usage and adoption of cloud computing by small and medium businesses," International Journal of Information Management, 33(5), pp. 861-874.

Gutierrez, A., Boukrami, E., and Lumsden, R. (2015). "Technological, organizational and environmental factors influencing managers' decision to adopt cloud computing in UK," Journal of Enterprise Information Management, 28(6), pp. 788-807.

Hair, J. T., Anderson, R. E., Tatham, R. L., and Black, W. C. (1992). Multivariate Data Analysis with Readings, $3^{\text {rd }}$ ed. Macmillan, New York. 
Hart, P. and Saunders, C. S. (1997). "Power and Trust: Critical Factors in the Adoption and Use of Electronic Data Interchange," Organization Science, 8(1), pp. 23-42.

Ifinedo, P. (2011). "Internet/e-business technologies acceptance in Canada's SMEs: An explorative investigation," Internet Research, 21(3), pp. 255-281.

Katzan, H. (2010). "On the privacy of cloud computing," International Journal of Management and Information Systems, 14(2), pp. 1-12.

Khan, N. and Al-Yasiri, A. (2016). "Framework for cloud computing adoption: A road map for SMEs to cloud migration," arXiv preprint arXiv:1601.01608.

Kula, V., and Tatoglu, E. (2003). "An exploratory study of Internet adoption by SMEs in an emerging market economy," European Business Review, 15(5), pp. 324-333.

Kumar, D., Samalia, H. V., and Verma, P. (2017). "Exploring suitability of cloud computing for small and mediumsized enterprises in India", Journal of Small Business and Enterprise Development, https://doi.org/10.1108/ JSBED-01-2017-0002.

Lippert, S. K., and Govindarajulu, C. (2006). "Technological, organizational, and environmental antecedents to web services adoption", Communications of the IIMA, 6 (1), pp. 147-160.

Low, C., Chen, Y., and Wu, M. (2011). "Understanding the determinants of cloud computing adoption," Industrial management and data systems, 111(7), pp. 1006-1023.

Makena, J. N. (2013). "Factors that affect cloud computing adoption by small and medium enterprises in Kenya," International Journal of Computer Applications Technology and Research, 2(5), pp. 517-521.
Malviya, A., and Chakraborty, N. (2013). "Increased MSME and Global Entrepreneurship Due to Cloud Computing," Global Journal of Management and Business Studies, 3(6), pp. 659-666.

Marston, S., Li, Z., Bandyopadhyay, S., Zhang, j. and Ghalsasi, A. (2011). "Cloud computing - the business perspective," Decision Support Systems, 51(1), pp. 176-189.

Mell, P. and Grace, T. (2011). "The NIST definition of cloud computing," NIST Special Publication 800-145, pp. 2-3, available at: http://nvlpubs.nist.gov/ nistpubs/Legacy/SP/nistspecialpublica tion800-145.pdf (accessed 1 February 2017).

Oliveira, T. and Martins, M. F. (2011). "Literature review of information technology adoption models at firm level," The Electronic Journal Information Systems Evaluation,14(1), pp. $110-121$.

Oliveira, T., Thomas, M., and Espadanal, M. (2014). "Assessing the determinants of cloud computing adoption: An analysis of the manufacturing and services sectors," Information and Management, 51(5), pp. 497-510.

Pan, M. J., and Jang, W. Y. (2008). "Determinants of the adoption of enterprise resource planning within the technology - organization environment framework: Taiwan's communications industry," Journal of Computer information systems, 48(3), pp. 94-102.

Prasad, A. and Green, P. (2015). "Cloud computing services for the small and medium enterprises: Key considerations for sourcing sustainable business value," In 2015 International Symposium on Accounting Information Systems, 29-30 October 2015, Orlando, FL. 
Ramdani, B., Kawalek, P., and Lorenzo, O. (2009). "Predicting SMEs' adoption of enterprise systems," Journal of Enterprise Information Management, 22(1/2), pp. 10-24.

Rogers, E. M. (2003). Elements of diffusion. 5th ed., Free Press, New York.

Safari, F., Safari, N., and Hasanzadeh, A. (2015). "The adoption of software-asa-service (SaaS): ranking the determinants," Journal of Enterprise Information Management, 28(3), pp. 400-422.

Senyo, P. K., Effah, J., and Addae, E. (2016). "Preliminary insight into cloud computing adoption in a developing country," Journal of Enterprise Information Management, 29(4), pp. 505-524.

Shen, Z., and Tong, Q. (2010). "The security of cloud computing system enabled by trusted computing technology," In Signal Processing Systems (ICSPS), 2010 2nd International Conference on (Vol. 2, pp. V2-11). IEEE, 5-7 July 2010, Dalian, China.

Shiralashetti, A. S. (2012). "Prospects and Problems of MSMEs in India-A Study," International Journal of in Multidisciplinary and Academic Research, 1(2), pp. 1-7.

Subashini, S. and Kavitha, V. (2011). "A survey on security issues in service delivery models of cloud computing," Journal of Network and Computer Applications, 3(1), pp. 1-11.

Sultan, N. (2011). "Reaching for the cloud: How SMEs can manage," International Journal of Information Management, 31(3), pp. 272-278.

Tan, S. K., Chong, S. C., Lin, B., and Eze, U. C. (2009). "Internet-based ICT adoption: evidence from Malaysian SMEs," Industrial Management and Data Systems, 109(2), pp. 224-244.
Thong, J. Y. L. (1999). "An Integrated Model of Information Systems Adoption in Small Businesses," Journal of Management Information Systems, 15(4), pp. 187-214.

Tornatzky, L., and Fleischer, M. (1990). The Process of Technology Innovation, Lexington Books, Lexington, MA.

Wang, R., Fu, Z. and Duan, Y. (2011). "Management and Service Science (MASS)," 2011 International Conference on. 12-14 Aug. 2011.

Wang, R., Fu, Z., and Duan, Y. (2011, August). "Understanding ICTs adoption from an evolutionary process perspective", in Management and Service Science (MASS), 2011 International Conference on (pp. 1-4). IEEE.

Wang, Y. M., Wang, Y. S. and Yang, Y. F. (2010). "Understanding the determinants of RFID adoption in the manufacturing industry," Technological Forecasting and Social Change, 77(5), pp. 803-815.

Wu, W. W. (2011). "Developing an explorative model for SaaS adoption," Expert systems with applications, 38(12), pp. 15057-15064.

Wu, W. W., Lan, L. W., and Lee, Y. T. (2013). "Factors hindering acceptance of using cloud services in university: a case study," The Electronic Library, 31(1), pp. 84-98.

Yeboah-Boateng, E. O., and Essandoh, K. A. (2014). "Factors influencing the adoption of cloud computing by small and medium enterprises in developing economies," International Journal of Emerging Science and Engineering, 2(4), pp. 13-20.

Yigitbasioglu, O. M. (2015). "The role of institutional pressures and top management support in the intention to adopt cloud computing solutions," Journal of Enterprise Information Management, 28(4), pp. 579-594. 
Zhu, K., Kraemer, K. L., and Xu, S. (2006). "The process of innovation assimilation by firms in different countries: a technology diffusion perspective on e-business," Management science, 52(10), pp. 1557-1576.
Zikmund, W. G., Babin, B. J., Carr, J. C. and Griffin, M. (2010). Business Research Methods, 8th Edition, South-Western Cengage learning. 


\section{Appendix I: Questionnaire Items}

\begin{tabular}{|c|c|c|c|}
\hline Construct & ID & Item & Sources \\
\hline \multirow{4}{*}{$\begin{array}{l}\text { Perceived } \\
\text { usefulness }\end{array}$} & PU1 & $\begin{array}{l}\text { Cloud computing services enable us to accomplish tasks } \\
\text { more quickly }\end{array}$ & \multirow[t]{4}{*}{$\begin{array}{l}\text { Grandon and } \\
\text { Pearson(2004) }\end{array}$} \\
\hline & PU2 & Cloud computing services will increase productivity & \\
\hline & PU3 & $\begin{array}{l}\text { Using cloud computing services give us greater control } \\
\text { over our work. }\end{array}$ & \\
\hline & PU4 & $\begin{array}{l}\text { Using cloud computing services would make my job } \\
\text { easier }\end{array}$ & \\
\hline \multirow{4}{*}{$\begin{array}{l}\text { Perceived } \\
\text { ease of use }\end{array}$} & PE1 & $\begin{array}{l}\text { Learning to operate cloud computing services would be } \\
\text { easy }\end{array}$ & \multirow[t]{4}{*}{$\begin{array}{l}\text { Alam et al. } \\
(2011)\end{array}$} \\
\hline & PE2 & $\begin{array}{l}\text { Our interaction with cloud computing services would be } \\
\text { clear and understandable }\end{array}$ & \\
\hline & PE3 & $\begin{array}{l}\text { It would be easy for us to become skilful at using cloud } \\
\text { computing services }\end{array}$ & \\
\hline & PE4 & $\begin{array}{l}\text { Overall we would find cloud computing services easy to } \\
\text { use }\end{array}$ & \\
\hline \multirow{5}{*}{$\begin{array}{l}\text { Relative } \\
\text { advantage }\end{array}$} & RA1 & $\begin{array}{l}\text { With cloud computing it is easy to 'scale-up' or 'scale- } \\
\text { down' IT resources as per requirements. }\end{array}$ & \multirow[t]{5}{*}{$\begin{array}{l}\text { Safari et al. } \\
(2015)\end{array}$} \\
\hline & RA2 & $\begin{array}{l}\text { Use of cloud computing services reduces upfront costs } \\
\text { (Initial investment on IT) }\end{array}$ & \\
\hline & RA3 & $\begin{array}{l}\text { Upgrading/updating \& maintenance of hardware \& } \\
\text { software is easy with cloud computing }\end{array}$ & \\
\hline & RA4 & $\begin{array}{l}\text { Back-up \& disaster recovery capabilities are better while } \\
\text { using cloud computing }\end{array}$ & \\
\hline & RA5 & $\begin{array}{l}\text { By using cloud computing we can easily get access to } \\
\text { latest information technologies. }\end{array}$ & \\
\hline \multirow[t]{4}{*}{ Compatibility } & $\mathrm{CO} 1$ & $\begin{array}{l}\text { Using cloud service is compatible with all aspect of our } \\
\text { work }\end{array}$ & \multirow[t]{4}{*}{$\begin{array}{l}\text { Wang et al. } \\
(2010)\end{array}$} \\
\hline & $\mathrm{CO} 2$ & $\begin{array}{l}\text { Usage of cloud computing service fits well with the way } \\
\text { we like to work }\end{array}$ & \\
\hline & $\mathrm{CO} 3$ & $\begin{array}{l}\text { Cloud computing created changes are compatible with } \\
\text { our business }\end{array}$ & \\
\hline & $\mathrm{CO} 4$ & $\begin{array}{l}\text { Cloud computing is compatible with our existing } \\
\text { technology infrastructure }\end{array}$ & \\
\hline \multirow{3}{*}{$\begin{array}{l}\text { Security and } \\
\text { privacy }\end{array}$} & SP1 & $\begin{array}{l}\text { The security systems built into the cloud computing } \\
\text { services are strong enough to protect our data }\end{array}$ & \multirow[t]{3}{*}{$\begin{array}{l}\text { Oliveira et al. } \\
\text { (2014) }\end{array}$} \\
\hline & SP2 & $\begin{array}{l}\text { The confidentiality of business data is guaranteed when } \\
\text { using cloud computing services }\end{array}$ & \\
\hline & SP3 & $\begin{array}{l}\text { I am confident that cloud providers will not use my } \\
\text { company's data for their own commercial benefits. }\end{array}$ & \\
\hline \multirow[t]{4}{*}{$\begin{array}{l}\text { Technology } \\
\text { readiness }\end{array}$} & TR1 & $\begin{array}{l}\text { When we come to know about new information } \\
\text { technology, we would look for ways to experiment with } \\
\text { this new IT. }\end{array}$ & \multirow[t]{4}{*}{ Wu (2011) } \\
\hline & TR2 & $\begin{array}{l}\text { Among peers, our firm is usually the first to adopt new } \\
\text { information technologies. }\end{array}$ & \\
\hline & TR3 & Cloud computing is a familiar type of technology to use & \\
\hline & TR4 & $\begin{array}{l}\text { Overall, my organization has enough technical } \\
\text { knowledge regarding technologies similar to cloud } \\
\text { computing }\end{array}$ & \\
\hline Top & TOP1 & $\begin{array}{l}\text { Top management's attitude is positive towards using } \\
\text { cloud computing }\end{array}$ & Ifinedo (2011) \\
\hline
\end{tabular}




\begin{tabular}{|c|c|c|c|}
\hline \multirow{3}{*}{$\begin{array}{l}\text { management } \\
\text { support }\end{array}$} & TOP2 & $\begin{array}{l}\text { Top management supports the implementation of cloud } \\
\text { services }\end{array}$ & \\
\hline & TOP3 & $\begin{array}{l}\text { Top management is ready to provide necessary } \\
\text { resources for the introduction of cloud computing }\end{array}$ & \\
\hline & TOP4 & $\begin{array}{l}\text { Top management accepts possible risks, which may } \\
\text { result from introducing cloud computing }\end{array}$ & \\
\hline \multirow[t]{3}{*}{ Firm size } & FS1 & Type of organization (Micro, Small, Medium) & \multirow{3}{*}{$\begin{array}{l}\text { Low et al. } \\
(2011)\end{array}$} \\
\hline & FS2 & Annual turnover & \\
\hline & FS3 & Number of employees & \\
\hline \multirow{4}{*}{$\begin{array}{l}\text { External } \\
\text { pressure }\end{array}$} & EP1 & $\begin{array}{l}\text { My company may acquire competitive edge if we use } \\
\text { cloud computing }\end{array}$ & \multirow[t]{4}{*}{$\begin{array}{l}\text { Alshamaila et al. } \\
(2013)\end{array}$} \\
\hline & EP2 & $\begin{array}{l}\text { Competition may prove to be an important factor in our } \\
\text { decision to adopt cloud computing }\end{array}$ & \\
\hline & EP3 & Our business partners are already using cloud computing & \\
\hline & EP4 & Our industry is pressuring us to adopt cloud computing & \\
\hline \multirow{3}{*}{$\begin{array}{l}\text { Service } \\
\text { providers' } \\
\text { support }\end{array}$} & SPS1 & $\begin{array}{l}\text { Cloud service provider's reputation is an important factor } \\
\text { while deciding about cloud computing implementation }\end{array}$ & \multirow[t]{3}{*}{$\begin{array}{l}\text { Al-Isma'ili et al. } \\
(2016)\end{array}$} \\
\hline & SPS2 & $\begin{array}{l}\text { It is necessary to have adequate technical support after } \\
\text { adoption of cloud computing services. }\end{array}$ & \\
\hline & SPS3 & $\begin{array}{l}\text { It is important to have a good relationship with cloud } \\
\text { service providers. }\end{array}$ & \\
\hline \multirow{3}{*}{$\begin{array}{l}\text { Adoption } \\
\text { intention }\end{array}$} & Al1 & $\begin{array}{l}\text { Assuming we have access to cloud computing, we intend } \\
\text { to use it. }\end{array}$ & \multirow[t]{3}{*}{$\begin{array}{l}\text { Gangwar et al. } \\
(2015)\end{array}$} \\
\hline & Al2 & $\begin{array}{l}\text { Given that we have access to cloud computing, we } \\
\text { predict that we would use it }\end{array}$ & \\
\hline & Al3 & $\begin{array}{l}\text { Given easy access to cloud computing, I will recommend } \\
\text { cloud computing implementation in my company. }\end{array}$ & \\
\hline
\end{tabular}

\section{About the Authors}

Devesh Kumar is pursuing $\mathrm{PhD}$ in the area of Information Systems from LM Thapar School of Management, Thapar University, Patiala, India. $\mathrm{He}$ is also serving as an Associate Professor in the Faculty of Management Sciences \& Liberal Arts at Shoolini University, Solan, India. His research interest includes technology adoption, e-learning and ICT4D. Mr. Kumar has published a number of research papers in peer reviewed academic journals and has presented papers in international conferences. He had the opportunity to work as MIS Incharge in a World Bank sponsored project on Education in India. He has also served as Assistant Professor in Ethiopia.

Harsh Vardhan Samalia is working as Associate Professor at Rajiv Gandhi Indian
Institute of Management, Shillong, India. Mr. Harsh Vardhan Samalia has done his doctoral work in the area of Strategic Management and Intellectual Property Rights from ABV-Indian Institute of Information Technology and Management, Gwalior, India. He completed his Master in Business Administration from Indian Institute of Information Technology and Management, Gwalior, India.

Piyush Verma is working as Associate Professor at LM Thapar School of Management, Thapar University, Patiala, India. Mr. Verma has done his doctoral work in the area of Applied Economics from the University of Lucknow, India. He completed his Master's in Business Economics from Punjabi University, Patiala, India. He has also been associated with IIM Lucknow, India. 